\title{
Sociological Foundations of Success of Turkish Tv Soap Operas in the Balkans
}

\section{Fundamentos socológicos del éxito de las telenovelas turcas de televisión en los Balcanes}

\author{
Ferhan Gündüz \\ Başkent University, Faculty of Literature and Science, Department of Sociology \\ ORCID: https://orcid.org/0000-0002-9969-2099
}

Received 01-12-20 Revised 01-25-20 Accepted 04-13-20 On line 06-29-20

*Correspondence

Email: fgunduz@baskent.edu.tr
Cite as:

Gündüz, F. (2020). Sociological Foundations of Success of Turkish Tv Soap Operas in the Balkans. Propósitos $y$ Representaciones, 8 (SPE2), $\quad$ e797. Doi: http://dx.doi.org/10.20511/pyr2020.v8nSPE2.797 


\section{Summary}

For the last decade, Turkish TV series particularly soap operas have been alluring an increasing rate of viewers both in Turkey and 76 countries around the world, spreading from Latin America to the Far East. This article examines the sociological foundations of high levels of interest in Turkish TV series in the Balkan region since relationships between the Turks and other people in this geographic area have a long history. As well, today's reflections of this historical relationship date back to the fifth century in so many ways. Turkish TV series have thus captured the social and cultural proximity of individuals living in these two geographies in the best sense and have also raised their awareness in this respect. A total of 15 out of 76 TV series released in Turkey until 2016 have been so far exported to Balkan countries and they have received enough attention. Accordingly, it is of utmost importance to determine the sociological foundations of this development.

Keywords: Turkish TV Series; Soap Operas; Bourdieu, Field Theory; Economic, Social and Cultural Capital; Tendency to Watch Series in Balkan Countries; Sociological Elements in TV Series.

\section{Resumen}

Durante la última década, las series de televisión turcas, en particular las telenovelas, han atraído a un número creciente de televidentes tanto en Turquía como en 76 países de todo el mundo, extendiéndose desde América Latina hasta el Lejano Oriente. Este artículo examina los fundamentos sociológicos de los altos niveles de interés en las series de televisión turcas en la región de los Balcanes, ya que las relaciones entre los turcos y otras personas en esta área geográfica tienen una larga historia. Además, las reflexiones de hoy de esta relación histórica se remontan al siglo $\mathrm{V}$ de muchas maneras. Las series de televisión turcas han capturado así la proximidad social y cultural de las personas que viven en estas dos geografías en el mejor sentido y también han aumentado su conciencia al respecto. Hasta el momento, un total de 15 de las 76 series de televisión lanzadas en Turquía hasta 2016 se han exportado a los países de los Balcanes y han recibido suficiente atención. En consecuencia, es de suma importancia determinar los fundamentos sociológicos de este desarrollo.

Palabras clave: Serie de televisión turca; Telenovelas; Bourdieu, teoría del campo; Capital económico, social y cultural; Tendencia a ver series en los países de los Balcanes; Elementos sociológicos en series de televisión.

\section{Introduction}

In this study, the sociological foundations of the success of Turkish TV series in the Balkans was determined based on the Structure-Action Theory developed by Bourdieu in which structureaction that included pure structure or pure individual were abridged, and there were more attempts to unite this dual structure (Swartz, 2015). The framework of this theory consists of the concepts of capital and habitus. Accordingly, habitus is not exactly individual and also fails to determine behavioral action alone. As stated by Bourdieu, habitus is a structure mechanism that works within individuals and principles of producing strategies enabling it to deal with a variety of situations. Habitus, as the product of internalization of external structures, additionally reacts more or less consistently and systematically to demands in a social field (Bourdieu \& Wacquant, 2016, p. 27). 
Bourdieu maintains that "the structure of the field is defined by the types of capitals that are effective upon that field" (Bourdieu \& Wacquant, 2016, p. 94). These types of capitals affecting the social field are economic, cultural, and social. Capitals may even exist and function in relation to a specific field. Social field is thus the name given to the place of power relations and struggles aimed at changing them. In short, the social field is a place of constant change (Bourdieu \& Wacquant, 2016, p. 89). For Bourdieu, the social field represents a fighting venue filled with conflicts and competitions (Bourdieu \& Wacquant, 2016, p. 26). According to Bourdieu, TV is a communication device that is under pressure due to its brutal competitive relationships, which have little autonomy. It also focuses on the fact that $\mathrm{TV}$, as a competitive fighting venue, should not underestimate its power in transforming its producers especially its cultural ones (Bourdieu, 1997, p. 41).

The sociological foundations of the success of TV series within the field of competition and struggle can be accordingly discussed with the concepts of economic, cultural, and social capitals raised by Bouirdieu. He also points to the sum of culturally acquired predispositions leading to formation of patterns of appreciation and understanding internalized through socialization process by individuals with cultural capital (Swartz, 2015, p. 111). In addition, Bourdieu's emphasis on historicality is of importance in this study. According to Bourdieu, the most significant things occur at the level of the structural history of the whole universe, so what matters in a field is their relative weight (Bourdieu, 1997, p. 48). Bourdieu, holding on to the idea whether sociology and history can be intertwined or not, underlines the value of historicality and believes that "without historicality, history cannot be made, without sociology, sociological perspective". Accordingly, meanings in networks of relationships, shapes of relationships gained in a historical process, and knowledge given on a subject can be correctly understood (Özsöz, 2007, p. 17).

Turkey has rapidly developed in the film industry particularly film and series shootings over the last decade. Therefore, state contribution transferred to this sector, other supporters, as well as advertising revenues are playing a major role in increasing production, marketing, exports, and growing rate of viewers. The series sector is developing to the extent that it is leading to dynamism in Turkey's economic activity. According to 2016 data released by the General Directorate of Cinema of the Ministry of Culture and Tourism of the Republic of Turkey, between 2005 and 2015, the total number of films increased from 221 to 406, and the number of domestic films multiplied from 27 to 139 . The total number of viewers also grew from 27 million to 61 million and the number of domestic film viewers rose from 11 million to 35 million. In 2015, the total gross was 684 million, while the gross from domestic films was close to 367 million liras. In 2005, the gross share of domestic films was $39 \%$ and that was $60 \%$ for the gross share of foreign ones. In 2015, the gross share of foreign films was $46 \%$ and that was grossed 53\% for domestic cases. In 2015, 8 of the top 10 most-watched films were domestic (Box Office Data 2015 Turkish Vision Report, 2015).

In recent years, many Turkish films have been also awarded at major international festivals. The awards won in the best director, film, and short film categories at Cannes, Berlin, and Venice Film Festivals, as the most important festivals in Europe in this field, are an indication of the success of Turkish cinema (Aktaş, Doğanay, \& Bozdağ, 2014, p. 90). Number of viewers in the film industry has even exceeded by 50 million in 2013. Turkish viewers' interest in local films has additionally increased the number of productions. The success of Turkish cinema in the domestic market in the past decade and the growing rate of viewers are undoubtedly balanced with the investments made in this resepct. It is not easy to see the success of Turkish cinema in the domestic market after they are exported. Turkish films have won international awards, but 
this success has not yet been commercialized. Moreover, very few Turkish films in the world are shown in countries with a large Turkish population, such as Germany and Austria in, general (Aktaş Doğanay, \& Bozdağ, 2014, p.101).

Undoubtedly, Turkish TV series have been influenced by the quality of the films that have been successful in this country. Thus, they have found a market all over the world and achieved a very successful level in the Middle East and the Balkans. Since the mid-2000s, there has been a noticeable rising trend in the exports of Turkish TV series. These large-budget weekly productions have been thus sold to the Middle East, the Balkans, and Central Asia, and more recently to countries in Latin America, Europe, and Asia. Beginning in the 2000s in Turkey, economic, industrial, and artistic exchange and production took place in parallel with the number of sectors, redoubling consumption and exports (Yeşil, 2015). In short, Turkey increased its exports of TV series in 2013 which reached $\$ 150$ million, released in more than 50 countries (Aktaş, Doğanay, \& Bozdağ, 2014, p.101).

TV's long watching time and advertising market share have accordingly affected rapid development of the series industry. TV also ranks first with $98.6 \%$ when it is investigated for distribution according to the type of device that viewers follow in Turkey. This is followed by computers $(7.9 \%)$, mobile phones $(0.2 \%)$, and other devices $(0.1 \%)$ (RTÜK, 2013, p. 8). In addition, according to the data released by the Turkish Statistical Institute, it has been observed that dependence on TV in Turkey has augmented. The most frequent social activity of individuals aged 10 and over is TV watching with $94 \%$. Considering working status and gender variability as well as time distribution allocated to various activities, the ratio of TV and video viewing is in the first place with $46 \%$ in total. Working and non-working men (46.7\%) compared with those (42.7\%) who do not work (42.8\%) are seen to spend time watching TV and video than working women $(47.3 \%)(44.5 \%)$ (TUIK, 2015). With regard to TV viewing behavior, it is observed that domestic series are more effective than other categories of programs, and this is a trend in all TV channels competing with each other. The frequency of TV shows includes domestic series (77\%), news (75\%), and Turkish films (50\%) (RTÜK, 2013, p. 25). Domestic series with the highest rating among the types of programs also constitute the most preferred one in the analysis of the five programs with the highest values. Domestic series also rank first with $38 \%$ in the distribution of five high-rating programs, followed by domestic series-summary and replay (14\%), competitions (25\%), foreign cinema (5\%), domestic cinema (4\%), and other options (14\%). The total of local series and domestic series-summary and replay categories is also by $52 \%$ (Özertem, 2014 , p. 10-11). The domestic series industry has led to advertising, sponsorship revenues, and domestic tourism mobility and has correspondingly made great contributions to the Turkish economy. Istanbul Chamber of Certified Public Accountants (ISMMMO) series economics research (Press Release, 2008) has also focused on the costs per episode of the series varying between 100 and 300 thousand liras. It has additionally emphasized that the series, along with sponsorship and advertising revenues, have been leading to the emergence of an economy of approximately 1 billion liras. Among the main factors affecting the success of the series in Turkey is the promotional support of TV channels provided to the series with advertisements and trailers, processing of series episodes in a way that attracts viewers' high levels of interest, and strong scenarios and selection of famous actors who are known and hold an important place. Therefore, inclusion of popular actors in projects, production company's economic strength, previous achievements, as well as reputation and recognition have positively affected the success of the series (Özertem, 2014, p. 15). Looking at the history of the series in Turkey, the first step into series was taken by the Turkish Radio and Television Corporation (TRT) in the 1970s within the framework of public broadcasting and continued with Turkish literary adaptations in the 1980s, starting in 1990 wherein an increase in diversity with the movement of privatization was seen. A range of family-centered series, from neighborhood series to adaptations of foreign-sourced sitcoms as well as network and mafia series stand out. In recent years, Turkish novel adaptations have been also brought up (Baykal, 2015, p. 132-133). It can be seen that the adaptation of Turkish 
novels and the coming of the lives of historical characters attract much attention. This trend in Turkish TV shows strengthens Turkey's hand in the international series industry and enables it to find buyers in many countries around the world. According to the data released by the Prime Minister's Office of the Republic of Turkey in June 2014, production companies in this country are making more than 100 new productions per year, which are exported to 75 countries together with Turkey and find more viewers abroad. Turkey's annual series exports also totaled close to $\$ 200$ million in 2013. The Turkish TV industry has been even exported from the Balkans, the Middle East, and South America to Central Asia. Turkish series that have contributed significantly to Turkey's image have been thus managed to become one of the most-watched productions in the countries where they are shown, and more than 70 Turkish series have been until now exported to 75 countries. In 2013, after being exported to countries such as Russia, Ukraine, China, and Pakistan for the first time, this industry has even grown faster (The Coordination of Public Diplomacy of the Prime Minister's Office, 2014). Turkish TV series have also entered the Latin American market after the Balkans, Middle East, Eastern Europe, and North Africa, which have been associated for centuries. According to Ivan Sanchez, sales director of Global Agency, "1001 Night" series, after Chile, had been sold to Spanish TV channels broadcasting in Uruguay, Argentina, Colombia, Peru, and the United States. Today, almost every country in the region shows five or six series, some of which have been hit with record-breaking. Turkish series have also brought this country to the agenda by reaching high ratings in Latin America, especially in Argentina, Chile, and Uruguay (Oruç, 2014).

Annual revenue from the sale of Turkish TV series abroad has additionally reached $\$ 350$ million. Given that this figure was $\$ 10$ million in 2008, the great rise of the Turkish series sector is clearly evident. After 2023 , the target is $\$ 750$ million. Developments in the TV industry in the world have affected Turkey the most. For example, Turkish series are in the second place after US-Hollywood ones (Kara, 2014; Tan, 2017). Turkish series have also become an important market for production companies in Balkan countries and the Arab world in terms of common history, cultural ties, and physical proximity. Thus, it has opened new windows to the world and appeals to a wide geography. Previously sold for between $\$ 35$ and 50 per episode, this figure can today rise to $\$ 500,000$ (Prime Minister's Office of Public Diplomacy, 2014). The budget, shooting techniques, cast, and décor devoted to the production of American series have been highly developed, so it has an important share in the global market. In this respect, they have significant advantages over Turkish TV shows. However, Turkish series have become competitive with regard to American series with scenarios and scenes reflecting on cultural stereotype behavior in the Middle East, North Africa, and Southeast Europe, considering the Western lifestyle.

Reviewing some studies addressing those who watch Turkish TV shows in different countries, it has been observed that the structure of Turkish series that blends different cultures, especially the Anatolian values and traditions, as the cradle of cultures of the East and the West and the combination of the Western lifestyle have attracted viewers' attention. It is understood that the traditional way of living, which does not reject traditions in Turkish series, but is not traditional, is particularly effective on female viewers (Özertem, 2014, p. 31; Çevik, 2015, p. 431). In terms of the success of Turkish series, the budget allocated to the production of such programs is also very important. Therefore, it is necessary to examine the revenues of Turkish TV channels from series expenditures and TV shows. According to an analysis by Forbes Turkey, about 170 million liras were paid for the series in total in Kanal D, broadcasting 15 TV series during the 2014-2015 broadcast season. FOX TV, broadcasting 10 series, was the second most money-spending channel on series with approximately 140 million liras. TRT1, also spent 120 million liras by broadcasting 14 series during 2014-2015 broadcast season. As well, ATV paid 108 million liras for 15 series in the same season, drawing a much more economical outlook than 
other channels, and SHOW TV allocated a budget of 50 million liras for such series (Forbes, 2015, p. 42).

The series sector in Turkey continues to grow each year. In 2008, Forbes Turkey’s topearning series producers ranked the list of the 20 highest-earning producers in which the total turnover of 450 million liras in 2014-2015 broadcast season exceeded 700 million liras and the total size of the sector reached 800 million liras (Forbes, 2015, p. 39). The total turnover of the 20 highest-earning series producers in Turkey also increased by $15 \%$ compared with that in the previous season. As well, the 294 days were topped from September 1, 2014 to June 21, 2015 with 208 programs including 66 competing programs, 19 matches, and 1 motion picture (Forbes, 2015, p. 44).

\section{Balkan Countries and Turkey}

The Balkans is a residential area where human life has been going from the beginning of known history. It has hosted various civilizations. Nevertheless, it has not escaped from being the conflict zone of the forces in the East and the West. This area has been subjected to great wars and migrations since the early days. This has led to the fact that the Balkan geography's life experience is very diverse and rich. Today, Balkan countries or Southeast European states in geography include Albania, Bosnia and Herzegovina, Bulgaria, Montenegro, Kosovo, Macedonia, and Greece. Parts of the territory of Serbia, Croatia, Slovenia, Hungary, and Turkey are also at the borders of this geography. The long-reigning rule of the Ottoman Empire also began when it prevailed in the Kosovo War in 1389, and the 19th century was the first time that the Ottomans had won the Kosovo War. It lasted until the 19th century. Balkan wars as well as the First and the Second World Wars also weakened relations between the Ottoman Empire or Turks and Balkan countries during the cold war. However, the establishment of the Balkan Pact with a protocol signed by Turkey, Greece, Romania, and Yugoslavia in Athens on February 9, 1934, was an important initiative for regional peace and a foundation for today's trust relations (Önal \& Ultan, 2012, p.77). Nevertheless, it is observed that relationships and values open to developments are increasing these days as those before wars. Indeed, the Balkan geography is one of the lands bearing the social and cultural heritage of the Ottoman Empire. The effects of this heritage, which sits back more than five hundred years, can be observed in the field of culture, lifestyle, habits, and traditions. Once more, the presence of a dense population migrating from the Balkans to Turkey and from Turkey to Balkan countries has been also instrumental in transferring and sharing this legacy. For Turkey, the Balkans has been a region of importance, both in terms of foreign policy and strategic, humanitarian, and cultural dimensions. The Balkans is Turkey's window to the West. Turkey is also closely interested in the stability of countries in the Balkans as connecting routes to Western European countries (Ceçen, 2016, p. 8).

In addition, the presence of more than one million Turkish minority and other Muslim populations in the region has always kept Turkey's interest in the Balkans alive (Türbedar, 2011, p. 141). Following the dissolution of the Soviet Union, new states and political conjunctures, emerged from regime changes in a significant part of the Balkan countries in the 1990s along with the breakup of Yugoslavia, which were new to Turkey's foreign policy approach in this geographical area but created new problems. In particular, the disappearance of ideological differences as well as economic and political problems faced by many Balkan states under new regimes increased Turkey's opportunities to expand cooperation and influence in this region. The Organization of the Black Sea Economic Cooperation (BSEC), established in 1992, including states such as Romania, Bulgaria, Albania, Greece, was one of the steps taken in this direction (Oran, 2002, p. 406-7; Ekinci, 2014, p. 104). However, civil wars and political problems in the Balkans together with the 1990s affected stability in the region, as well as Turkey's more active 
role in this geographic area. As a result of the break-up in Yugoslavia, the threats faced by the Muslim population resulted in Turkey's dominance as a patron. In this context, Turkey has been involved in peacekeeping forces in Bosnia and Herzegovina and Kosovo and has additionally played an active role in peace talks (Linden \& Irepoğlu, 2013, p. 232; Vračić, 2014).

\section{Foundatıons of Success of Turkısh Tv Series in Balkan Countries}

Positive developments in Turkey's relations with Balkan countries have given Turkish TV series a chance to be shown in many countries in this region. In a short period of time, a large number of Turkish series have broken watching records and reached quite considerable segments in these countries. Turkish series, which have gained great popularity in the Middle East, have also found their place in Balkan countries. Even in states such as Serbia and Greece, wherein there are serious prejudices against Turkey, such series have achieved significant success (Akgün \& Gündogan, 2012). Interest in Turkish films and TV series in the Balkans has even reached a level that has surprised film producers in Turkey. Today, people in Bosnia and Herzegovina, Kosovo, Macedonia, Serbia, and Croatia have started to take the subject of Turkish films they watched the night before in their daily conversations (Mihalakopoulos, 2011, p. 186).

This interest in Turkish TV series in the Balkans has significantly increased interest in Turkish culture, the Turkish language, and Turkey itself. As a result of increased interest in Turkish in Balkan countries, there has been a considerable growth in the number of students of Balkan origin who prefer universities in Turkey to learn the Turkish language (Bayraktar, 2012, p. 187). In a study aimed at investigating whether the Turkish series in the Albanian capital, Tirana, could help viewers learn and develop languages from the series or attract their interest, it was revealed that interest in this language had been awakened in viewers (Sögüttlü \& Söğütlü 2013 ). As the circulation of these series has grown in the international arena, learning the Turkish language and culture has become very important in the Arab world and Balkan countries. This is exactly what is called "soft power" in the context of the culture industry (Arisoy, 2016, p. 137). It is stated that the series sector should be regarded as a means of public diplomacy, playing a role in formation of perceptions about Turkey and production of popular culture of the series. It is also emphasized that Turkey contributes significantly to its image and soft power by the series, and that a Western identity blended with Oriental values enhances the attractiveness of the cultural products (Çevik, 2015, p. 424, 431).

The series produced in Turkey have become one of the most-watched channels in the countries where they are shown. The cast in the series have also become highly recognized in these countries (Carney, 2014, p. 34). When the most-watched "Silver" series was first published by the Arab satellite channel, Mbc, in 2008, it made a strong entrance into the Arab world. Mbc's own viewers have thus become more than 84 million watching one of the most popular programs on Arab TV (Kraidy, 2014, p. 12). At the end of 2011, a total of 10,500 hours of series and content have been also exported to many countries in the Balkans, the Middle East, and Africa, according to the Ministry of Culture and Tourism of the Republic of Turkey. Revenues from these exports have also exceeded $\$ 60$ million annually (Karakaya, 2013, p. 26). Today, it is stated that 400 million people are watching Turkish TV series with interest in 75 countries. For example, "the Magnificent Century" is watched by 250 million viewers around the world. The sale price of Turkish series abroad ranges from $\$ 500$ to $\$ 200,000$ per episode (Turkish Series Record, 2014).

The interest of other Balkan countries, particularly Greece, on Turkish TV series dates back to 2005. In the summer, described as a dead season in 2005, Greek TV Channel Mega released the series called "Foreign Groom" (Yabancı Damat in Turkish or Borders of Love in 
Greek). In 2005, the story of the Greek Nikos and the Turk Nazl1, reached 1,2 million viewers during the summer and the lives of the actors that were starring in the TV series became the top story in TV magazines. The series, which tells the love story of the Greek Nikos and the Turk Nazli who met and fell in love with each other in Bodrum, was met with great interest in Greece. This TV series discusses the relationship between young Greek men and Turkish women, and the problems they face, particularly the prejudices of historical anti-Greek-Turkish biases encountered in intercultural relationships (Mihalakopoulos, 2011, p. 184-85).

Watching Turkish series with interest in many Balkan countries was with the series "1001 Nights" (Binbir Night in Turkish). In 2010, the series was first released in Macedonia and soon in Greece. It achieved great success in Macedonia (40\%) and it also reached a fan base of more than one million in Greece (Mihalakopoulos, 2011, p. 185). The popularity of the TV series was not limited to this, but it was marketed to Balkan countries including Croatia, Bulgaria, Serbia, Romania, Albania, Bosnia and Herzegovina, and Montenegro. The TV series also received much attention around here especially in Zagreb, Croatia, with the very great impact of "1001 Nights" introducing "Welcome" and "Estağfurullah" among the words mentioned in the series (DipnotTV, 2014). After the influence created by "1001 Nights", new Turkish series were shown on TV channels of Balkan countries. In 2010, Turkish series such as "Kismet" (Dudaktan Kalbe in Turkish), "Bitter Life" (Ac1 Hayat in Turkish), and "Silver" (Gümüș in Turkish) were released in Greece. In 2011, "Ezel", "North South", and "Bitter Life" were also shown in Greece, Albania, Bulgaria, Serbia, Croatia, Romania, Macedonia, and Bosnia and Herzegovina (Mihalakopoulos, 2011, p. 186). In 2012, Bulgaria bought a total of 27 series from Turkey. According to a study by the Mareco Index Bosnia, 13 Turkish series were shown on different TV channels in Bosnia and Herzegovina in 2013, 9 cases in Macedonia, 4 series in Serbia, and 3 cases in Kosovo when "the Magnificent Century", "As Time Goes By", became one of the most-watched series in these countries (Turks Bewitch the Balkans with their Addictive Soaps, 2013). The competition was organized in Bosnia and Herzegovina, which was the most resembling "Sultan Suleiman" and "Hürrem Sultan", as one of the leading actors in the series "Magnificent Century", attracted a lot of attention from OBN TV, and the competition resonated greatly on social media. Those winning the competition were also promised a trip to Istanbul (Nuroğlu, 2013, p. 8). In 2013, "What is Fatmagül's Fault" in Kosovo received the most ratings, while "Love and Punishment" came in the third place. In Macedonia, in the same year, there were two most-watched series, "As Time Goes By" and "Asi" (Turks Bewitch the Balkans with their Addictive Soaps, 2013).

\section{Reasons for Popularity of Turkish TV Series in the Balkans}

The intense interest in Turkish TV series particularly soap opera spreading rapidly in the Balkans has led to controversies in many areas. The subjects of the series are similar to the forms of human relationships that are common in the Balkan geography. The folkloric patterns in the places used and the high levels of empathy created by cultural patterns have also made the debate spark positively. The series have been exhibited by choosing social reality in Turkey. The visibility of Turkish TV shows lies in highlighting the association between tradition and modernity as well as secularism and religion (i.e. Islam) that are at odds in many countries of the world (Frank, 2016, p. 53). The series have chosen a very careful and secular framework for featuring certain traditional, cultural, and religious elements in the content. Again, the high production quality of Turkish series lies in the attractiveness of the venues used and the processing of emotional relationships (Emin, 2013). According to Serbian sociologist, Ratko Bozovic, Serbian people witness cultural and linguistic similarities while watching Turkish TV shows and enjoy recognizing these common elements. The unease created by the rapid change observed in Serbian society, especially in family life and structure has also led to much interest in Turkish series that often center on family. In fact, the idea about the values of the family, which is thought to be facing the threat of oblivion, is being remembered with Turkish series. As stated by Kosovo sociologist, Artan Muhaxhiri, there are both cultural similarity and affinity between Albanians 
and the Turkish people as the underlying cause of the success of Turkish TV series in Albania and Kosovo (Turks Bewitch the Balkans with their Addictive Soaps, 2013). In the study focused on those who had watched Turkish TV series in Albania and had discussed reasons for popularity of Turkish TV series, it had been determined that emphasis on family and familial ties in the series had been effective. This was an awakening tradition among the Albanians in the last 10-15 years. Other factors attracting Albanian viewers were common history (Albanians lived with the Turks for 500 years during the Ottoman Empire), cultural resemblance, and traditional intimacy (Sögütlü \& Söğütlü, 2013).

Greek journalist and writer, Nikos Chiladakis, also revealed the forgotten aspects of Turkish TV series especially in monitoring of these series, which showed the importance of family, family relations, place of women, and respect as an important value. According to Greek anthropologist, Penelope Papailias, the Greek people have rediscovered their common relationships, historical ties, and cultural heritage with the Turkish people, whom they have lived with for many years (Moore, 2013). The documentary Kismet, was also released in 2013 and centered on the popularity of Turkish series in the Middle East and the Balkans. One of the reasons why Turkish TV series are so popular is that the ratio of female viewers is high. In interviews in this documentary, women's stereotypes in defying strong and traditional values in Turkish TV series provide an intense interest in both Middle Eastern countries and Balkan states especially "Silver", "Forbidden Love" (Aşk-1 Memnu in Turkish), "What is Fatmagül's Fault?", “As Time Goes By", and "the Magnificent Century". Under the success of such series, female viewers are committed to identifying themselves with the female characters. According to the documentary, these series function as a means for breaking taboos and inspiring female viewers to achieve success (Pashalidou, 2014).

Another reason for the success of Turkish TV series in the Balkans is that countries in this geographic area have faced an economic and political crisis since 2008. Many people who want to get away from the difficulties and troubles of everyday life have made Turkish series popular in the Balkans, which are easy to follow, have a lot of characters to identify with, and offer humor and melodrama together. Furthermore, the economic crisis and stagnation have affected the preference of Turkish series at a lower cost (Yörük \& Vatikiotis, 2013). For example, most of Greece's private TV channels are choosing Turkish TV shows for the same reason as US ones, to reduce the budgets of Greek productions due to the economic crisis and to include the most-watched Turkish series at a lower financial cost. Each episode of a Greek series ranges from 70,000 to 80,000 euros, while each part of a Turkish series costs about 7,000 to 8,000 euros. While some circles fear a cultural invasion of Turkish TV series to be shown in Greece, others consider it as an opportunity to recognize people's daily lives (Mihalakopoulos, 2011, p. 186).

As it turns out, some researchers believe that the success of Turkish TV series in the Balkans is based on cultural intimacy as well as common history, traditions, and values. They also explain the reason for this with reference to regional characteristics, Turkey's proximity to the Balkans, historical effects, and memories left by the Ottoman Empire in the region. According to some other researchers, the success of Turkish series is due to the fact that they address daily subjects and problems that are the product of popular culture as well as banned elements. Turkish series have further established a new market industry by offering a contemporary, rich, and exciting lifestyle that is attractive to many viewers and branding their own products and lifestyles. Thus, while representing wealthy, contemporary, and secular elites, they have become alluring to different viewers who "miss desirable wealth objects and lost values" (Frank, 2016, p. 47). 


\section{Effects of Success of Turkish Series in the Balkans}

With their different reactions, Turkish TV series have become popular in the Balkans since 2010. Turkish culture in Balkan countries and the image of the Turkish language and Turkey by itself have thus rapidly with these series. The fact that most Balkan countries have long remained under Ottoman Empire rule has led them to look at Turkey with suspicion and prejudice. Nevertheless, the fact that these series are being watched in these countries has had a positive effect. According to Sejn Husejnefendic at Sarajevo University, "1001 Night" series exemplified the series that made significant changes in closed Muslim countries and women with their ignorant and mandependent perceptions of Turkey (Rousselin, 2013, p.17). As mentioned above, Turkish series have increased interest in the Turkish language and traditions in the region. As explained by sociologist Nilüfer Narl1, it has become more important to know the Turkish language and culture in Middle East states and Balkan countries with the introduction of Turkish series in the international arena. Of course, this is what is referred to as "soft power" in the context of the cultural industry (Mihalakopoulos, 2011, p. 183).

Ekinci (2014, p.116) also revealed positive changes in "Attitudes of People in Balkan Countries towards Turkey", based on research findings by Gallup Balkan Monitor. The results of the research, covering a time period between 2008 and 2011, are as follows:

Table 1. Attitudes of people in Balkan Countries towards Turkey (\%)

\begin{tabular}{|c|c|c|c|c|}
\hline \multirow{2}{*}{ Countries } & \multicolumn{2}{|c|}{ 2008 } & \multicolumn{2}{c|}{ 2011 } \\
\cline { 2 - 5 } & Friendly & Hostile & Friendly & Hostile \\
\hline Albania & 80.0 & 0.50 & 69.2 & 0.8 \\
\hline BosniaandHerzegovina & 41.0 & 20.08 & 50.6 & 8.6 \\
\hline Croatia & 23.4 & 9.10 & 33.5 & 3.4 \\
\hline Montenegro & 22.2 & 9.20 & 30.4 & 9.6 \\
\hline Kosovo & 79.3 & 3.30 & 92.7 & 1.0 \\
\hline Macedonia & 77.9 & 1.5 & 70.3 & 1.0 \\
\hline Serbia & 12.9 & 22.80 & 14.4 & 19.0 \\
\hline
\end{tabular}

As seen from the Table 1 , the image of Turkey tends to improve significantly in the mentioned countries. There has been also a rise in friendly attitudes towards Turkey and a decrease in hostile ones. This improvement coincides with Turkey's intense relationships with these countries, both as an economic power and as a cultural force with Turkish TV series particularly soap operas. Moreover, perceptions that the new Foreign Policy of Turkey are new Ottomanism, especially in 2008, has increased suspicions in some Balkan countries and has further provoked some extreme reactions. In 2012, for example, Turkish TV shows became so popular in Macedonia that changes to TV law were brought up to prevent it from being broadcast and debated in the parliament. Macedonian Minister of Information Society, Ivo Ivanovski, who brought the change of law, reacted by saying that "no matter how beautiful these series were, they did not want to re-enter 500 years of Turkish captivity" (Zalewski, 2016).

Although it has not taken any effect, this incident shows reactions to Turkish TV series. Similarly, Thessaloniki Bishop Antimos and the ultranationalist Golden Dawn Party believed that Turkish TV shows had targeted the national consciousness of the Greek people, calling them not to be monitored (Dabilis, 2012; Moore, 2013). 
The reactions to the impact of Turkish TV series are not limited to these issues. The success of such series and the arrival of intense viewers have drawn the reaction of some ultranationalist and conservative factions in Balkan countries and have also sparked different debates in various countries. Some people consider Turkish TV series to be a secret weapon that this country uses to gain power in the Balkans and to spread its own cultural politics in this geography. In fact, a common joke about Turkish TV shows is said in many Balkan countries that "when the Ottomans are withdrawing from the Balkans, we will return with the series" (Nuroğlu, 2013, p. 8).

In short, Turkish TV series in the Balkans are perceived in a negative and positive way. The former means that people understand the influence of Turkish series in an orientalized manner, and frame them as a Turkish threat in the form of "invasion", "expansion", "contamination", and as another neo-Ottoman imperialist and colonial attempt. They also criticize Turkish soap operas from an idealized historical and nationalist point of view (Frank, 2016, p. 48).

\section{Reflections of Success of Turkish Series in the Balkans}

The popularity of Turkish TV series in Balkan countries has broken and changed prejudices in Turkey and Turkish culture. It has also made significant contributions to the country's economy. Turkey has accordingly managed to promote its own exports and its cultural values and lifestyle in nearby geographies. Many actors playing in Turkish series have also become a star in Balkan countries. In addition, as a result of the influence created by these series, an influx of tourists from Balkan countries has begun in Turkey. According to the Ministry of Culture and Tourism of the Republic of Turkey, the number of tourists from Western Balkan countries alone was 182,233 in 1997, compared with 550,422 in 2012 (Ekinci, 2014, p. 116). For example, comparing the figures for August 2012 to 2013, the number of tourists from Bosnia and Herzegovina increased by $46 \%$. Tourists from Serbia, wherein the perception of Turkey has been negative for many years, also appear to grow by $12 \%$ over the same period (Nuroglu, 2013, p. 3). With the historical and natural beauties of most Turkish series, the city of Istanbul is constantly in the series. Special trips are even organized to visit the places where the most popular series are filmed. Moreover, people buy clothes and accessories worn in Turkish TV shows. "There has also been an increase in exports of design products such as architecture, fashion, interior design, jewelry, and toys" (Karlıdağ \& Bulut, 2014, p. 88). A survey of more than 2,000 people from Balkan countries including Bulgaria, Croatia, Macedonia, and Serbia by Istanbul Civilization University revealed that they had never been to Turkey and regularly $80 \%$ of those watching Turkish series wanted to come to Turkey. Looking at the number of tourists coming to Turkey after 2006, it was established that the increase in tourists from countries importing Turkish series was greater than the growth in the total number of tourists (Gür, 2014, p. 4). As this data shows, there is an irreparable parallel between the success of Turkish TV series in the Balkans and the impact it has had and the rising number of tourists coming to Turkey from Balkan countries.

\section{Conclusion}

In this study, the sociological foundations of Turkey's influence in TV series and the Balkans were emphasized. According to Bourdieu, pure structure or pure individual was abridged, and there have been attempts to unite this dual structure. Turkish TV series, which now have a total annual export value of 60 million euros, have gained a huge popularity in the Balkans in 2010 after the Middle East. The Turkish series, which first began in the Balkans with the series "1001 Night" have correspondingly resulted in marketing of other series to many Balkan countries such as "the Magnificent Century", "As Time Goes By", "Asi", and "Ezel” which have even reached 
a huge number of viewers in this region. The popularity of Turkish TV shows has also led to the beginning of prejudices against Turkey in the Balkans. Turkey's image, which is generally perceived as a closed country, has changed significantly. The success of Turkish series has even induced the memory of the common values of the people living in the Balkans with the Turkish people from the Ottoman Empire heritage. Characters, roles, perpetrated values, cultural patterns, and relationships in the series overlap with those in Balkan countries. Turkey's changing image has also given a significant rise to the number of tourists coming from the Balkans to Turkey. These developments and strengthened economic and political aspects by further cooperation with the countries in this geographic area are also important for Turkey, as a candidate for the European Union.

From here, the provisions of the concepts of field, capital, and habitus, forming the framework of Bourdieu's Structure-Action Theory can be pointed out. The structure of the social field is defined by the types of economic, cultural, or social capitals. For Turkey, it is easy to see that the Balkan countries have these social and cultural capitals. As the third type of capital, the relations in the framework on which economic activities are based can be established through TV series. Once the quality gained by investments in the series is added, the multiplier effect of other types of capitals can feed the appeal of Turkish TV series. Therefore, as emphasized by Bourdieu, TV as a competitive and challenging place has been effective enough to transform both itself and cultural producers.

References

Akgün, M., \& Gündoğar, S. S. (2012). TESEV Dış Politika Programı Ortadoğu'da Türkiye Algısı. İstanbul: TESEV.

Akgün, M., \& Gündoğar, S. S. (2012). TESEV Dış Politika Programı Ortadoğu'da Türkiye Algısı. İstanbul: TESEV.

Aktaş, R., Doğanay, M., Bozdağ, Ş., \& Karaduman vd., A. B. (2014). Study on the Economic Contribution of Copyright Industries in Turkey. World Intellectual Property Organization, Creative Industries Series No. 8.

Arısoy, C. (2016). Turkish Series: Products of Popular Culture and Tools for Inclusive Globalization. Online Journal of Communication and Media Technologies, 6, 129-142.

Arısoy, C. (2016). Turkish Series: Products of Popular Culture and Tools for Inclusive Globalization. Online Journal of Communication and Media Technologies(6), 129-142.

Arısoy, C. (2016). Turkish Series: Products of Popular Culture and Tools for Inclusive Globalization. Online Journal of Communication and Media Technologies, 6, 129-142.

Arısoy, C. (2016). Turkish Series: Products of Popular Culture and Tools for Inclusive Globalization. Online Journal of Communication and Media Technologies(6), 129-142.

Basın Bülteni. (2008, 10 4). 01 29, 2018 tarihinde ismmmo.org.tr: http://archive.ismmmo.org.tr/docs/basin/2008/bulten/04102008_DiziEkonomisi.pdf adresinden alınd 1

Basin Bülteni. (2008, 10 4). 01 29, 2018 tarihinde ismmmo.org.tr: http://archive.ismmmo.org.tr/docs/basin/2008/bulten/04102008_DiziEkonomisi.pdf adresinden alınd 1

Başbakanlık Kamu Diplomasisi Koordinatörlüğ̈̈ . (2014, Haziran). 01 23, 2018 tarihinde Türkiye'nin Dizi Film İhracatı 200 Milyon Dolara Ulaştı: https://kdk.gov.tr/haber/turkiyenin-dizi-film-ihracati-200-milyon-dolara-ulasti/362 adresinden alınd 1 
Başbakanlık Kamu Diplomasisi Koordinatörlügü̈ . (2014, Haziran). 01 23, 2018 tarihinde Türkiye'nin Dizi Film İhracatı 200 Milyon Dolara Ulaştı: https://kdk.gov.tr/haber/turkiyenin-dizi-film-ihracati-200-milyon-dolara-ulasti/362 adresinden alınd 1

Baykal, K. C. (2015). Uluslararası Yeni Medya Yeni Yaklaşımlar Konferansı. Televizyon Dizileri İçin Alternatif Ve Özgür Bir Mecra Olarak Internet Siteleri (s. 131-150). Çanakkale: Çanakkale Onsekiz Mart Üniversitesi İletişim Fakültesi.

Baykal, K. C. (2015). Uluslararası Yeni Medya Yeni Yaklaşımlar Konferansı. Televizyon Dizileri İçin Alternatif Ve Özgür Bir Mecra Olarak Internet Siteleri (s. 131-150). Çanakkale: Çanakkale Onsekiz Mart Üniversitesi İletişim Fakültesi.

Bayraktar, Z. (2012). Türkiye'nin Balkanlardaki Yumuşak Gücü Türk Kültürü. Karadeniz Araştırmaları, 35(35), 181-189.

Bayraktar, Z. (2012). Türkiye'nin Balkanlardaki Yumuşak Gücü Türk Kültürü. Karadeniz Araştırmaları, 35(35), 181-189.

Bourdieu, P. (1997). Televizyon Üzerine. (T. Ilgaz, Çev.) İstanbul: Yapı Kredi Yayınları.

Bourdieu, P. (1997). Televizyon Üzerine. (T. Ilgaz, Çev.) İstanbul: Yapı Kredi Yayınları.

Bourdieu, P., \& Wacquant, L. (2016). Düşünümsel Bir Antropoloji İçin Cevaplar. (N. Ökten, Çev.) İstanbul: İletişim.

Bourdieu, P., \& Wacquant, L. (2016). Düşünümsel Bir Antropoloji İçin Cevaplar. (N. Ökten, Çev.) İstanbul: İletişim.

Carney, J. (2014). Silver and Light: Turkish Drama Shines Brighter Abroad. J. Carney, M. Kraidy, L. Nocera, \& S. Torelli içinde, The Turkish Touch Neo-Ottoman Hegemony and Turkish Television in the Middle East (s. 33-36). The Publications by Arab Media Repor.

Carney, J. (2014). Silver and Light: Turkish Drama Shines Brighter Abroad. J. Carney, M. Kraidy, L. Nocera, \& S. Torelli içinde, The Turkish Touch Neo-Ottoman Hegemony and Turkish Television in the Middle East (s. 33-36). The Publications by Arab Media Repor.

Çeçen, A. (2016). Türkiye ve Balkanlar. Ankara: Astana Yayınları.

Çeçen, A. (2016). Türkiye ve Balkanlar. Ankara: Astana Yayınları.

Çevik, B. (2015). Kültürel Diplomaside Devlet Dışı Aktörler: Türk Sinaması ve Dizileri. M. Şahin, \& B. Çevik içinde, Kamu Dış Politikası ve Kamu Diplomasisi (s. 391-437). Ankara: Nobel.

Çevik, B. (2015). Kültürel Diplomaside Devlet Dışı Aktörler: Türk Sineması ve Dizileri. M. Şahin, \& B. Çevik içinde, Türk Dış Politikası ve Kamu Diplomasisi (s. 391-437). Ankara: Nobel.

Çevik, B. (2015). Kültürel Diplomaside Devlet Dışı Aktörler: Türk Sinaması ve Dizileri. M. Şahin, \& B. Çevik içinde, Kamu Dış Politikası ve Kamu Diplomasisi (s. 391-437). Ankara: Nobel.

Çevik, B. (2015). Kültürel Diplomaside Devlet Dışı Aktörler: Türk Sineması ve Dizileri. M. Şahin, \& B. Çevik içinde, Türk Dış Politikası ve Kamu Diplomasisi (s. 391-437). Ankara: Nobel.

Dabilis, A. (2012, Oct 14). Turkish TV Series' Success in Greece to Spread. Mart 12, 2018 tarihinde greece.greekreporter.com: http://greece.greekreporter.com/2012/10/14/turkishtv-series-success-in-greece-to-spread/ adresinden alınd1

Dabilis, A. (2012, Oct 14). Turkish TV Series' Success in Greece to Spread. Mart 12, 2018 tarihinde greece.greekreporter.com: http://greece.greekreporter.com/2012/10/14/turkishtv-series-success-in-greece-to-spread/ adresinden alınd1 
Dipnot.tv. (2014, 10 6). Türk Dizileri Balkanlar'da Neden Bu Kadar Popüler? 2 1, 2018 tarihinde www.dipnot.tv: $\quad$ 13http://www.dipnot.tv/turk-dizileri-balkanlarda-neden-bu-kadarpopuler/78095/ adresinden alındı

Dipnot.tv. (2014, 10 6). Türk Dizileri Balkanlar'da Neden Bu Kadar Popüler? 2 1, 2018 tarihinde www.dipnot.tv: 13http://www.dipnot.tv/turk-dizileri-balkanlarda-neden-bu-kadarpopuler/78095/ adresinden alınd1

Ekinci, M. U. (2014). A Golden Age of Relations: Turkey and the Western Balkans During the AK Party Period. Insight Turkey, 16(1), 103-125.

Ekinci, M. U. (2014). A Golden Age of Relations: Turkey and the Western Balkans During the AK Party Period. Insight Turkey, 16(1), 103-125.

Emin, N. (2013, 5 9). Balkanlar'da Türk Dizilerine Olan Ilgiyi Nasıl Okumalı? 11 26, 2017 tarihinde Setav: https://www.setav.org/balkanlarda-turk-dizilerine-olan-ilgiyi-nasilokumali/ adresinden alınd

Emin, N. (2013, 5 9). Balkanlar'da Türk Dizilerine Olan İlgiyi Nasıl Okumalı? 11 26, 2017 tarihinde Setav: https://www.setav.org/balkanlarda-turk-dizilerine-olan-ilgiyi-nasilokumali/ adresinden alındı

Forbes. (2015, Temmuz 1). Türkiye'nin En Çok Kazanan Dizİ Yapımcıları. Forbes, s. 38-44.

Forbes. (2015, Temmuz 1). Türkiye'nin En Çok Kazanan Dizİ Yapımcıları. Forbes, s. 38-44.

Frank, A. (2016). Representations of Contemporary Turkey, the Ottoman Empire, Islam, and Gender through the Phenomenon of Modern Pop Culture the Case of Turkish Soap Operas in the Western Balkans. (M. S. Kafkasyali, Dü.) Balkanlarda İslam Miadı Dolmayan Umut, 5, s. 43-76.

Frank, A. (2016). Representations of Contemporary Turkey, the Ottoman Empire, Islam, and Gender through the Phenomenon of Modern Pop Culture the Case of Turkish Soap Operas in the Western Balkans. (M. S. Kafkasyali, Dü.) Balkanlarda İslam Miadı Dolmayan Umut, 5, s. 43-76.

Gişe Verileri 2015 Yll Türkiye Vizyon Raporu. (2015). 12 30, 2017 tarihinde T.C. Kültür Ve Turizm Bakanlığ1: http://sinema.kulturturizm.gov.tr/TR,144746/gise-verileri.html adresinden alınd 1

Gişe Verileri 2015 Yılı Türkiye Vizyon Raporu. (2015). 12 30, 2017 tarihinde T.C. Kültür Ve Turizm Bakanlığı: http://sinema.kulturturizm.gov.tr/TR,144746/gise-verileri.html adresinden alınd 1

Gür, N. (2014, 7). Yeni Türkiye’nin Yumuşak Güç Unsuru: Turizm. 1 13, 2018 tarihinde setav.org: http://file.setav.org/Files/Pdf/20140804151240_turkiyenin-yumusak-guc-unsuruturizm.pdf adresinden alınd

Gür, N. (2014, 7). Yeni Türkiye'nin Yumuşak Güç Unsuru: Turizm. 1 13, 2018 tarihinde setav.org: http://file.setav.org/Files/Pdf/20140804151240_turkiyenin-yumusak-guc-unsuruturizm.pdf adresinden alınd 1

Haberturk.com. (2012, 11 13). Türk Dizileri Yasaklanıyor! 3 2018, 2018 tarihinde haberturk.com: http://www.haberturk.com/medya/haber/793848-turk-dizileri-yasaklaniyor adresinden alınd 1

Haberturk.com. (2012, 11 13). Türk Dizileri Yasaklaniyor! 3 2018, 2018 tarihinde haberturk.com: http://www.haberturk.com/medya/haber/793848-turk-dizileri-yasaklaniyor adresinden alınd1

Kara, A. (Dü.). (2014, 2 21). Türkiye Dizi İhracatında Hollywood'dan Sonra İkinci. 2 20, 2018 tarihinde https://onedio.com/haber/turk-dizilerinin-rekoru-256009 adresinden alındı

Kara, A. (Dü.). (2014, 2 21). Türkiye Dizi İhracatında Hollywood'dan Sonra İkinci. 2 20, 2018 tarihinde https://onedio.com/haber/turk-dizilerinin-rekoru-256009 adresinden alındı 
Karakaya, M. (2013). Bir Bakışta Türk Medyası . Ankara: TC Başbakanlık Basın-Yayın ve Enformasyon Genel Müdürlüğü.

Karakaya, M. (2013). Bir Bakışta Türk Medyası . Ankara: TC Başbakanlık Basın-Yayın ve Enformasyon Genel Müdürlüğü.

Karlıdağ, S., \& Bulut, S. (2014). The Transnational Spread Of Turkish Television Soap Operas*/Türk Tv Dızılerının Ulusötesı Yayılımı. İstanbul Üniversitesi Iletisim Fakültesi Dergisi(47), 75-96.

Karlıdağ, S., \& Bulut, S. (2014). The Transnational Spread Of Turkısh Television Soap Operas*/Türk Tv Dızılerının Ulusötes1 Yayılımı. İstanbul Üniversitesi İletisim Fakültesi Dergisi(47), 75-96.

Kraidy , M. (2014). Neo-Ottoman Cool Turkish Television and Film in Arab Public Discourse. J. Carney, M. Kraidy, L. Nocera, \& S. Torelli içinde, The Turkish Touch Neo-Ottoman Hegemony and Turkish Television in the Middle East (s. 11-20). The Publications by Arab Media Report.

Kraidy , M. (2014). Neo-Ottoman Cool Turkish Television and Film in Arab Public Discourse. J. Carney, M. Kraidy, L. Nocera, \& S. Torelli içinde, The Turkish Touch Neo-Ottoman Hegemony and Turkish Television in the Middle East (s. 11-20). The Publications by Arab Media Report.

Kültür-Sanat. (2014). Türk Dizilerinin Rekoru. 2 20, 2018 tarihinde www.aljazeera.com.tr: http://www.aljazeera.com.tr/al-jazeera-ozel/turk-dizilerinin-rekoru adresinden alınd1

Kültür-Sanat. (2014). Türk Dizilerinin Rekoru. 2 20, 2018 tarihinde www.aljazeera.com.tr: http://www.aljazeera.com.tr/al-jazeera-ozel/turk-dizilerinin-rekoru adresinden alınd1

Linden, R., \& İrepoğlu, Y. (2013). Turkey and the Balkans: New Forms of Political Community? Turkish Studies, 14(2), 229-255.

Linden, R., \& İrepoğlu, Y. (2013). Turkey and the Balkans: New Forms of Political Community? Turkish Studies, 14(2), 229-255.

Mihalakopoulos, G. (2011). The Greek Audience "Discovers" the Turkish. N. M. M. Tsianikas içinde, "Greek Research in Australia: Proceedings of the Biennial International Conference of Greek Studies, (s. 179-191). Flinders University.

Mihalakopoulos, G. (2011). The Greek Audience "Discovers" the Turkish. N. M. M. Tsianikas içinde, "Greek Research in Australia: Proceedings of the Biennial International Conference of Greek Studies, (s. 179-191). Flinders University.

Moore, R. (2013, 2 12). Soap Opera Diplomacy: Turkish TV in Greece. The International. adresinden alınmıştır

Moore, R. (2013, 2 12). Soap Opera Diplomacy: Turkish TV in Greece. The International. adresinden alınmıştır

Nuroğlu, E. (2013). Dizi Turizmi: Orta Doğu Ve Balkanlar'dan Gelen Turistlerin Türkiye'yi Ziyaret Kararinda Türk Dizileri Ne Kadar Etkili. . 5th International Conference of Istanbul Economists, (s. 1-13).

Nuroğlu, E. (2013). Dizi Turizmi: Orta Doğu Ve Balkanlar'dan Gelen Turistlerin Türkiye'yi Ziyaret Kararinda Türk Dizileri Ne Kadar Etkili. . 5th International Conference of Istanbul Economists, (s. 1-13).

Oran, B. (2002). Türk Dış Politikası Kurtuluş Savaşından Bugüne olgular, Belgeler, Yorumlar (Cilt II 1980-2001). İstanbul: İletişim Yayınları.

Oran, B. (2002). Türk Dış Politikası Kurtuluş Savaşından Bugüne olgular, Belgeler, Yorumlar (Cilt II 1980-2001). İstanbul: İletişim Yayınları. 
Oruç, Y. E. (2014, 12 1). Türk Dizileriyle Latin Açılımı. http://www.aljazeera.com.tr: http://www.aljazeera.com.tr/al-jazeera-ozel/turk-dizileriyle-latin-acilimi adresinden alınmıştır

Oruç, Y. E. (2014, 12 1). Türk Dizileriyle Latin Açılımı. http://www.aljazeera.com.tr: http://www.aljazeera.com.tr/al-jazeera-ozel/turk-dizileriyle-latin-acilimi adresinden alınmıştır

Önal, B., \& Ultan, M. (2012). Balkan Paktı (1934) Ve Dışarıdaki Yansımaları. Social Sciences Review of the Faculty of Sciences \& Letters University of Uludag/Fen Edebiyat Fakültesi Sosyal Bilimler Dergisi, 13(22), 65-84.

Önal, B., \& Ultan, M. (2012). Balkan Paktı (1934) Ve Dışarıdaki Yansımaları. Social Sciences Review of the Faculty of Sciences \& Letters University of Uludag/Fen Edebiyat Fakültesi Sosyal Bilimler Dergisi, 13(22), 65-84.

Özertem, T. (2014, Ağustos). Dünyanın En Renkli Ekranı Türkiye'de Dizi Sektörü. Deloitte.

Özertem, T. (2014, Ağustos). Dünyanın En Renkli Ekranı Türkiye'de Dizi Sektörü. Deloitte.

Özsöz, C. (2007). Pierre Bourdieu'nün Temel Kavramlarina Giriş. Sosyoloji Notları Dergisi(1), 15-21.

Özsöz, C. (2007). Pierre Bourdieu'nün Temel Kavramlarina Giriş. Sosyoloji Notları Dergisi(1), $15-21$.

Pashalidou , N. M. (2014, Jan 15). Kismet: How Soap Operas Changed the World. 02 14, 2018 tarihinde www.aljazeera.com: http://www.aljazeera.com/programmes/witness/2013/11/kismet-how-soap-operaschanged-world-20131117152457476872.html adresinden alınd1

Pashalidou , N. M. (2014, Jan 15). Kismet: How Soap Operas Changed the World. 02 14, 2018 tarihinde www.aljazeera.com: http://www.aljazeera.com/programmes/witness/2013/11/kismet-how-soap-operaschanged-world-20131117152457476872.html adresinden alınd1

Rousselin, M. (2013). Turkish Soap Power: International Perspectives and Domestic Paradoxes. StrategiDepth through Soft Power: The Domestic Production and International Projection of Turkish Culture, 16, 16-22.

Rousselin, M. (2013). Turkish Soap Power: International Perspectives and Domestic Paradoxes. StrategiDepth through Soft Power: The Domestic Production and International Projection of Turkish Culture, 16, 16-22.

RTÜK. (2013, Mart). (Kamuoyu, Yayın Araştırmaları Ve Ölçme Dairesi Başkanlığı) 01 23, 2018 tarihinde Televizyon İzleme Eğilimleri Araştırması - 2012: file:///C:/Users/User/Downloads/2013\%20Y\%C4\%B11\%C4\%B1\%20Ara\%C5\%9Ft\%C 4\%B1rmalar\%C4\%B1\%20(1)_0110\%20(1).pdf adresinden alınd 1

RTÜK. (2013, Mart). (Kamuoyu, Yayın Araştırmaları Ve Ölçme Dairesi Başkanlığı) 01 23, 2018 tarihinde Televizyon İzleme Eğilimleri Araştırması - 2012: file://C:/Users/User/Downloads/2013\%20Y\%C4\%B11\%C4\%B1\%20Ara\%C5\%9Ft\%C 4\%B1rmalar\%C4\%B1\%20(1)_0110\%20(1).pdf adresinden alındı

Söğütlü, E., \& Sögütlü, E. (2013 , DEC). Reasons for the Popularity of Turkish Soap Operas in Albania. BJES, 4(1).

Sögütlü, E., \& Söğütlü, E. (2013 , DEC). Reasons for the Popularity of Turkish Soap Operas in Albania. BJES, 4(1).

Swartz, D. (2015). Kültür ve iktidar: Pierre Bourdieu'nün Sosyolojisi. (E. Gen , Çev.) İstanbul: İletişim Yayınları.

Swartz, D. (2015). Kültür ve iktidar: Pierre Bourdieu'nün Sosyolojisi. (E. Gen , Çev.) İstanbul: İletişim Yayınları. 
Tan, E. (2017, 4 5). Türk Dizilerinden İhracat Rekoru: 2023 Hedefi 750 Milyon Dolar! www.donanimhaber.com: https://www.donanimhaber.com/sinema-vedizi/haberleri/Turk-dizilerinden-ihracat-rekoru-2023-hedefi-750-milyon-dolar.htm adresinden alınmıştır

Tan, E. (2017, 4 5). Türk Dizilerinden İhracat Rekoru: 2023 Hedefi 750 Milyon Dolar! www.donanimhaber.com: https://www.donanimhaber.com/sinema-vedizi/haberleri/Turk-dizilerinden-ihracat-rekoru-2023-hedefi-750-milyon-dolar.htm adresinden alınmıştır

TUİK. (2015, 12 4). Zaman Kullanım Araştırmast. 2 2, 2018 tarihinde Türkiye İstatistik Kurumu Haber Bülteni: Aktaş, R., Doğanay, M., Bozdağ, Ş., \& Karaduman vd., A. B. (2014). Study on the Economic Contribution of Copyright Industries in Turkey. World Intellectual Property Organization, Creative Industries Series No. 8.

TUİK. (2015, 12 4). Zaman Kullanım Araştırması. 2 2, 2018 tarihinde Türkiye İstatistik Kurumu Haber Bülteni: http://www.tuik.gov.tr/PreHaberBultenleri.do?id=18627 adresinden alınd 1

Turks Bewitch The Balkans With Their Addictive Soaps. (2013, 5 1). 1 13, 2018 tarihinde www.balkaninsight.com: http://www.balkaninsight.com adresinden alınd1

Turks Bewitch The Balkans With Their Addictive Soaps. (2013, 5 1). 1 13, 2018 tarihinde www.balkaninsight.com: http://www.balkaninsight.com adresinden alındı

Türbedar, E. (2011). Turkey's New Activism in the Western Balkans: Ambitions and Obstacles. Insight Turkey, 13(3), 139-158.

Vračić, A. (2014). A Political Romance: Relations between Turkey and Bosnia and Herzegovina. www.popilari.org.

Wacquant,, L., \& Bourdieu, P. (2016). Düşünümsel Bir Antropoloji Iç̧in Cevaplar. (N. Ökten, Çev.) İstanbul: İletişim Yayınları.

www.sozcu.com.tr. (2017, 07 27). 01 22, 2018 tarihinde Türkiye Dünyanın En Çok TV İzleyen İkinci Ülkesi: http://www.sozcu.com.tr/hayatim/kultur-sanat-haberleri/turkiyedunyanin-en-cok-tv-izleyen-ikinci-ulkesi/ adresinden alındı

www.sozcu.com.tr. (2017, 07 27). 01 22, 2018 tarihinde Türkiye Dünyanın En Çok TV İzleyen İkinci Ülkesi: http://www.sozcu.com.tr/hayatim/kultur-sanat-haberleri/turkiyedunyanin-en-cok-tv-izleyen-ikinci-ulkesi/ adresinden alındı

Yesil, B. (2015). Transnationalization of Turkish dramas: Exploring the convergence of local and global market imperatives. Global Media and Communication, 11(1), 43-60.

Yörük, Z., \& Vatikiotis, P. (2013). Soft Power or Illusion of Hegemony: The Case of the Turkish Soap Opera "Colonialism". International Journal of Communication, 7, 2361-2385.

Zalewski, P. (2016, 8 16). As Turkey Turns. 2 13, 2018 tarihinde slate.com: http://www.slate.com/articles/arts/roads/2013/08/turkish_soap_operas_go_global_turke y_s_homemade_melodramas_are_popular_across.html adresinden alındı 